Marte Sørebø Gulliksen

\title{
Alternative theoretical and methodological approaches for exploring higher education in Art and Crafts
}

\begin{abstract}
This article presents and discusses approaches for exploring higher education in Art and Crafts. The concepts exploring versus research and the different foci in an insider perspective versus an outsider perspective introduces the theme. An insider perspective is said to be a useful starting point for inquiry, referring to Frayling's trichotomy research into, research on and research through from 1993. The field of higher education in Art and Crafts education is shortly presented as comprising two main areas of knowledge: knowledge of education, and knowledge about the different subject areas within Art and Crafts. Both theory and practice are a part of these areas of knowledge. As higher education in Art and Crafts is a making profession, the most prominent challenge when exploring this today is thus said to be to develop research based knowledge on Education in Art and Crafts as a making discipline. Two keywords are deemed to be useful in approaching this theme: Mode 2 knowledge production and transdisciplinarity. The article concludes with describing specific ways of doing this today from within the context of application. Two examples of large research projects in Scandinavia are presented as examples of such projects.
\end{abstract}

Keywords: Art and Crafts education, insider/outsider perspective, making discipline, mode 2 knowledge production, context of application.

\section{Introduction}

In this article ${ }^{1}$ I present and discuss alternative theoretical and methodological approaches for exploring higher education in Art and Crafts. By using the word "exploring" rather than the phrase "doing research in", the article reflects the understanding that there are more knowledge generating explorative activities in this field, than simply that which fits under the heading "research". I refer here to the discussions following in the wake of Frayling's trichotomy "Research into, research on and research through" from 1993 (Frayling 1993). The latter, "research through" has proven to be a debatable issue from the time it was published.

"Research through the arts" is research or systematic explorative knowledge generating activities conducted by the insiders in the field. These insiders, in this article, are the practitioners of the field of Art and Crafts. They teach the subject in schools or at universities, and they make artefacts while maintaining a pedagogical perspective on their making activities. They have an embodied knowledge of the theory and the practice of the field. They also "seek [...] to articulate some of this embodied knowledge throughout the creative process and in the art object." (Borgdorf 2006:13). Frayling and those building on this perspective, such as Borgdorf, argue that when these practitioners study their field, and at the same time engage in art or design activities, they have the opportunity to recognize and evaluate aspects of what is important or relevant knowledge, activities or structures in a manner more precise than an outsider. These perspectives on practice based research functions as a backdrop for this article, and I will return to some aspects of these later.

Exploration and research within higher education in Art and Crafts has not, until very recently, been defined as a separate domain of research with the usual key-factors: a critical mass of researchers, publications or a specialized education on PhD-level. Because of this, professionals within the field wanting to qualify as researchers have received their training from established academic disciplines, for example within pedagogy, psychology, philosophy, art history, etc. (Nielsen 2008, Aakre \& Randers-Pehrson 2008). In these disciplines they have 
met other researchers doing research on the field of Art and Crafts. This has unavoidably led to an outsider-perspective onto the field.

Much useful knowledge has been generated from such outsider-perspective-studies, but it also poses several questions. While pedagogues examine areas in which they are interested, and use their theoretical models and preferred research methods, the historians, sociologists, psychologists, engineers, etc. are doing the same. This means that one and same event might be understood as very different things according to the eyes of the specific researcher. Take for example the sunbeam, which for the biologist will be understood as one thing, for the quantum mechanics specialist something entirely different and for the artist another again.

This, and more, may be reasons for the many claims of the field as "lacking a common ground." (Nielsen 2000, Johansson 2002, Lindström, Borg, Johansson, \& Lindberg 2003) and (Gulliksen 2002, 2004). This claim is not unique for the field of Art and Crafts alone; it also being said about many of the different professional art and design fields, or research in other school subjects (Friedman 2003, Borgdorf 2006, Jonas 2006). In the Millennium Programme at Oslo school of Architecture and Design (OSA), this challenge was taken up in one of the conclusions. Dunin-Woyseth and Nielsen identifies in Discussing Transdisciplinarity the need for new and alternative theoretical and methodological approaches in these fields, in order to address the fields' lacuna and educate new researchers to handle these. They write:

The teachers' evaluation concluded that the current status of the research education promised adequate training opportunities for the growing Scandinavian community of architectural and design researchers. Nevertheless, this preparedness seemed to apply mainly to traditional disciplinary and interdisciplinary academically-initiated research. Network teachers decided that the next phase of this co-operation should be committed to the preparation of young researchers, to meet the demands for new types of a broader research competence that of problems and solutions oriented research (Dunin-Woyseth \& Nielsen 2004a:5f).

In this article I expand on this perspective when I address some possible alternative ways of exploring higher education in Art and Crafts. What these ways have in common is a perspective built through some 12-14 years around the $\mathrm{PhD}$ programme at OSA, and referred to as the making professions and the making disciplines. I regard this as a promising path methodologically and theoretically. I will, in this article, briefly define Making disciplines, and I will then use examples to discuss more specifically some methodological and theoretical approaches to explore higher education within Art and Crafts on the field's own terms: from within. As a start, I will briefly present an outline of the field of Art and Crafts education and define some the key concepts used.

\section{The field Art and Crafts education}

Art and Crafts (Kunst og håndverk) is being taught in Norway throughout the lower and upper secondary schools, and it is taught in courses at Universities and University Colleges within the various teacher training educations. There is also a teacher training for Art and Crafts on bachelor level, and Art and Crafts is a subject and research area on master's level. When challenged to discuss "higher education in Art and Crafts", I therefore choose to focus on education at the Norwegian teacher training university colleges (Gulliksen 2006). However, I will to some extent also include teacher training in the Nordic equivalent subjects and educations within the professional fields of Arts, Design and Craft, where the likenesses between the fields are found useful and relevant.

Higher education in Art and Crafts has two main areas of knowledge: one part is knowledge about education and pedagogy, the other is knowledge about the different subject areas within Art and Crafts such as art, craft, design and education. These subject areas may 
also be given many different names depending on its specific context. In the curriculum for primary and lower secondary school they are referred to as Art, Design, Visual Communication and Arcitecture (Kunnskapsdepartementet 2006). In the general teacher education, the subject areas are the same (HiO 2009, HiT 2009), while in the teacher training in Art and Crafts, the subject areas are pedagogic, art history, subject theory, didactical/ pedagogical theory and practical aesthetical work (UFD 2003). The field of Art and Crafts therefore separates from other art and design fields because of its context of application, the educative situation.

If we factor in the difference between theory and practice in the equation, the complexity grows further. Ytterstad presented in 2002 a four-sector model of the competence for teachers in Art and Crafts (Ytterstad 2002) covering both theory and practice. Lutnæs developed this further in her article concerning competence of assessment in Art and Crafts (Lutnæs 2006).

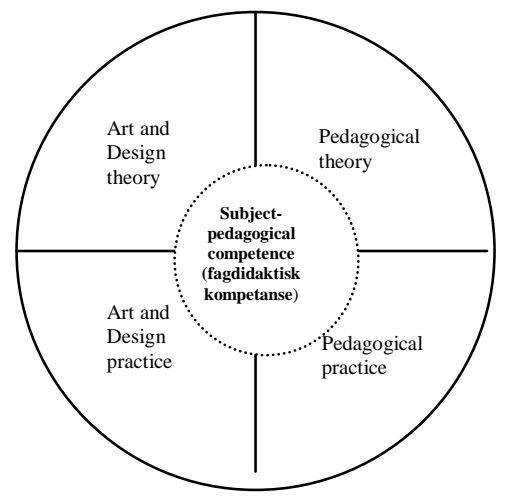

Figure 1: The competence for teachers in Art and Crafts. After Ytterstad 2002 and Lutnas 2006.

This model embraces both practice and theory as an inherent part of the field. A main feature of the Art and Crafts subject is this activity of making (Dunin-Woyseth \& Michl 2001, Lindström et al. 2003, Dunin-Woyseth \& Nielsen 2004b, 2004a, Gulliksen 2006). We teach and learn the domain-specific subject knowledge as we apply and develop our process and pedagogical knowledge (Christiaans \& Venselaar 2005).

In the different studies conducted into (or on or through) Art and Crafts, the focus has mainly been on this (problem-led-) activity. Of 14 doctoral theses written as of 2006 in Norway by scholars either from the field or scholars focusing on the field, 9 have focused on the activity itself. Further, of $13 \mathrm{PhD}$ projects on-going today, 11 are focusing on the activity. In the approximately six hundred master theses written within Art and Crafts, the picture is even clearer (Melbye 2008). It is a criterion in the master study that the thesis should consist of three parts: an exploration of one singular research problem through three dimensions: theory, pedagogic/educational theory, and practical aesthetic explorations. Therefore, all master theses focus on a larger or smaller element of the activity, though to different extent (Melbye 2003, 2006, 2008).

As a consequence, most studies within the field Art and Crafts comprise both domain specific knowledge in the singular area and general process knowledge. This makes them complex, and therefore challenging to communicate and use.

In order to address this challenge, it was suggested by the founders of the concepts making knowledge and making disciplines, that researchers should change their basic point of view. This implied that instead of (the more academically traditional) methodological approach of dividing the field into subdivisions of the theme, a more fruitful approach could be to emulate the making processes itself: to seek out and obtain the knowledge we need when we need it. Whether it be general process knowledge or domain-specific knowledge 
from one or another (academic) discipline (Dunin-Woyseth \& Nielsen 2004a). Such a point of view begins with the activity: the making in all its complexity. This might be referred to as a Copernican turn, a radical change in perspective on the object of research. Like the change of perspective which followed Copernicus' suggestion that the earth was evolving around the sun, not the sun around the earth.

\section{Making professions - making disciplines}

As stated previously, the concept making professions has been developed around the $\mathrm{PhD}$ courses at OSA. Central publications introducing this concept are (Dunin-Woyseth \& Michl 2001, Dunin-Woyseth \& Nielsen 2004a, 2004b). It is a collective term for fields which share the act of making as the common nominator. The word making "addresses the shaping of a broad spectrum of artefacts "from the spoon to the city" (Dunin-Woyseth \& Nielsen 2004a).

In order to generate new and relevant knowledge into, on and through the making processes, the Making disciplines were introduced, as a new conception of knowledge production. Making disciplines "provides a scholarly framework where making knowledge is being derived from, then scholarly processed, and, finally, directed back to design practice" (Dunin-Woyseth \& Nielsen 2004a:1).

The other way around to explore the field, before this Copernican turn as described above, possibly could be visualised like this,

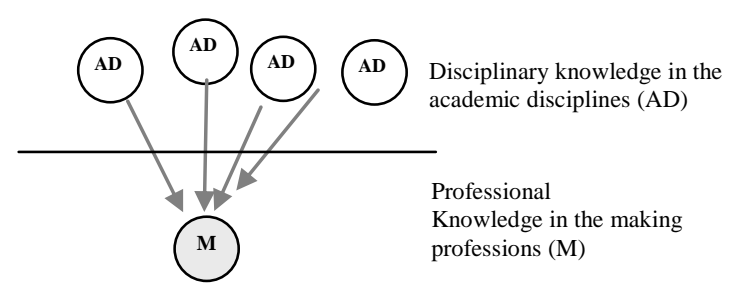

Figure 2: before the Copernican turn.

the new relation between making disciplines and the academic disciplines is visualized in this way by Dunin-Woyseth and Nielsen:

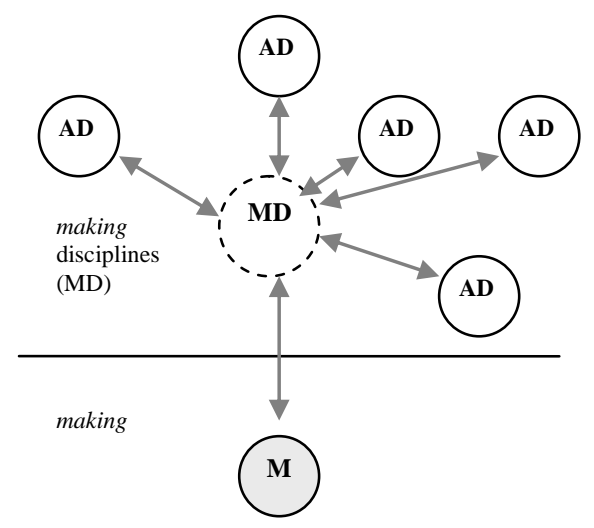

Figure 3: after the Copernican turn: (Diagram 1. A Making Discipline. Relations and Principles. (Dunin-Woyseth \& Nielsen 2004a:3)

Education in Art and Crafts is a making profession. It is thus possible that such a new point of view, a making discipline-perspective on Art and Crafts could provide a theoretical and methodological basis for researchers and practitioners in the field. In the next section I expand on this theme. 


\section{Research on Education in Art and Crafts as a making discipline}

Two keywords may be useful in approaching the theme research in Education in Art and Crafts as a making discipline: Mode 2 knowledge production and transdisciplinarity.

In The new production of knowledge from 1994, Gibbons et.al. discusses two modes of knowledge production. Their claim is that a "distinct set of cognitive and social practices is beginning to emerge and that these are different from Mode 1" (Gibbons et al. 1994:3) Here Mode 1 is the "traditional" academic research, while Mode 2 represents a new mode of knowledge production.

The following table presents some differences between Mode 1 and Mode 2:

\begin{tabular}{|l|l|}
\hline $\begin{array}{l}\text { Mode 1 } \\
\text { Problems are set and solved } \\
\text { "following the codes relevant to a particular } \\
\text { discipline" }\end{array}$ & $\begin{array}{l}\text { Mode 2 } \\
\text { Problem solving "is organized around a } \\
\text { particular application". A context of } \\
\text { application. }\end{array}$ \\
\hline Homogeneity & Heterogeneity and organisational diversity \\
\hline Disciplinary & Transdisciplinary \\
\hline Hierarchical and tends to preserve its form & Heterarchical and transient \\
\hline $\begin{array}{l}\text { Quality control is closely linked to Natural } \\
\text { Science methods etc. }\end{array}$ & $\begin{array}{l}\text { Quality control linked to a socially } \\
\text { accountability and reflexivity }\end{array}$ \\
\hline
\end{tabular}

Figure 4: Mode 1 vs. Mode 2, some differences. Based on (Gibbons et al. 1994).

Firstly, while in Mode 1, problems are set and solved "following the codes relevant to a particular discipline", problem solving in Mode 2 "is organized around a particular application". When exploring higher education in Art and Crafts from a Making perspective, the context of application is the education in making activity. This is most often conducted in studios by students engaging in making processes of their own. From this context of application the problem solving begins, and the results are generated back here.

Secondly, while Mode 1 is featured by homogeneity, Mode 2 is more heterogeneous. As mentioned above, the field of Art and Crafts comprises different areas of knowledge and practices. Therefore it is also may be said to be heterogeneous.

Thirdly, while Mode 1 knowledge production is limited to a single discipline, exploration or research within Art and Crafts has a potential for transdisciplinarity. Nowotny, one of the contributors to another book of Gibbon's, Re-Thinking Science from 2001 (Gibbons \& Scott 2001), discusses the potential of transdisciplinarity in her article by that name from 2004. She begins her discussion by saying that transdisciplinarity may be understood as a response to a felt need: we seek a unity of knowledge, and we believe that such a unity has been found previously. A transdisciplinary approach will perhaps help us regain such a unity, by combining the different, specialized fields of knowledge by means of the unifying theme or question. A transdisciplinary approach can also be advocated for more pragmatic motives, since "no discipline knows more than all disciplines" (Taddai, quoted by Nowotny 2004). If we could combine the efforts of different disciplines into joined problem solving we could "provide for an integration of perspectives in the identification, formulation and resolution" (Nowotny 2004). The outcome of such an exploration will be more valuable than if only one discipline were to study the same. As in the example of the sunbeam given previously whose explanation is closest to a full description of the actual sunbeam?

Most knowledge has an aspect of transgressiveness, Nowotny writes, "It seeps through institutions and structures like water through the pores of a membrane" (Nowotny 2004:10). Converting this transgressiveness to transdisciplinarity in Mode 2 knowledge production, you find four features. 
1. It has an evolving framework, that you are open to different approaches at the same time, and to change the approach during the course of the exploration if deemed necessary.

2. A transdisciplinary solution comprises both empirical and theoretical components. This is amongst other things due to the context of application: one begins from a specific situation, in Art and Crafts, the activity of making. Hence the term transdisciplinarity, not multidisciplinarity or pluri-disciplinarity. The transdisciplinary approach is open for methods, theory or in general intellectual activity which may not be from one particular discipline but a mixture of several disciplines. Nowotny continues "one set of conversations and instrumentation in the context of application leads to another, and another, again and again." (Nowotny 2004:11)

3. The results are communicated to the participants and diffusion of knowledge occurs as the participants move on to new situations.

4. It is dynamic, open for change. "There is a kind of convergence or co-evolution between what is happening in the sphere of knowledge production and how societal institutions are developing" (Nowotny 2004:12).

Together these four features focus on the transgressiveness of knowledge. In its most literal meaning, transgressiveness should be used to emphasise the usability, accountability and quality control of this knowledge.

Looking again on figure 4 presenting the differences between Mode 1 and Mode 2, this is a form of quality control which rest on criteria of social accountability and reflexivity. It should be useful. It is in the usefulness, that the potential of transdisciplinarity lies, Nowotny concludes.

\section{Alternative approaches, consequences of this perspective}

Returning to the theme exploration of higher education in Art and Crafts, where does such a perspective leads us? As quoted earlier, the organizers of Millennium Programme concluded that there is a potent need for more research focused around problems and less on singular disciplines (Dunin-Woyseth \& Nielsen 2004a). This is both an organizational issue, and a practical research methodological issue.

\section{An organizational issue}

How can we facilitate useful research within education in Art and Crafts? The organization of research activities in the face of this new need for research includes developing a critical mass of researchers and having them build history, theory and criticism within the field. There are many possible solutions to this challenge.

One answer is the type of research network called DesignDialogue, founded by Professor Liv Merete Nielsen at Oslo University College, and supported by Professor Halina Dunin-Woyseth at OSA. This is a network for researchers within Art and Crafts, open to PhD candidates, post doc candidates and full professors as a "community of research practice" inspired not only by Gibbons et.al's Mode 2 of knowledge production, but also Wengers theories of communities of practice (Nielsen 2004:10).

Another possible solution is the trend towards larger, collaborative, research projects. These projects allow the integration of a broader research competence in each project. Below I present examples of two such studies. 


\section{A practical research methodological issue}

Research on education in Art and Crafts as a making discipline leads us to the context of application: which entails a special approach to the activity, the making process. Gibbons et al.'s definition of context of application is:

Problem solving and the generation of knowledge organised around a particular application. Not merely applied research or development. Includes the milieu of interests, institutions and practices which impinge upon the problem to be solved (Gibbons et al. 1994:167).

Research in a context of application is intended to be useful. This could and has been conducted from different disciplines. However, an insider perspective opens for a transdisciplinary approach, and for knowledge production in Mode 2. Nevertheless, the labels which can be applied are less interesting than the actual possibilities of ways to proceed.

When exploring higher education in Art and Crafts in today's context, based in the perspective given above, the first and foremost rule should consequentially be the question: "What - in this activity - do I want to know more about? What is the context of application where this knowledge is found and knowledge is needed?" I will now give examples on such choices and the differences between them.

\section{Narrowing down a scope}

In an educative situation, a central context of application is the actual learning in the activity /practice. For the sake of argument in this article, I choose to exemplify quite specifically the need for narrowing down a scope in such an alternative methodological and theoretical approach. Take for example a research project aiming to describe how knowledge is constructed in this activity/practice in a social context? This aim will be imperative from the beginning and it implies that insights in this theme will be produced in a continuous negotiation between the interests of the various actors engaged in the study. What do they want to learn about the knowledge construction in their activity?

Although all activity in higher Art and Crafts education is a making activity with elements of learning and teaching, a research focus on the actual knowledge construction in the situation would be slightly different from research focuses like:

- the process of constructing a particular understanding, for example, a set of principles for judgement of form quality in the activity (as I did in my thesis) (Gulliksen 2006),

- the actual process of giving an artefact a specific form (as in the study of Refsum from 2000) (Refsum 2000),

- the actual process of inventing a solution to a design problem (as were shown many different ways of studying through one form of documentation, verbal protocol analysis, in the workshop "Analysing Design Activity" in 1994, published and edited by Cross et.al 1996) (Cross, Christiaans, \& Dorst 1996),

- the maker's experience in the activity (a study of the body-space interaction as $\mathrm{PhD}$ candidate Bro is conducting currently),

- the reasons for making the different choices in the process (for example based on decision making theory from psychology, Kahnemans availability heuristics etc) (Gulliksen 2008),

- the development of act drawing skills in the activity (a contextual, discursive and pragmatic study as Pedersens' PhD from 2004) (Pedersen 2004),

- the creation of meaning in a drawing process (a semiotic study, as Hopperstad did in 2002 ) (Hopperstad 2002, Ingebrethsen 2008). 
Yet the focus on the knowledge construction in the activity would still be too wide. More questions must be asked to narrow it down to a specific enough context of application. The two ongoing research projects presented below give examples of how this has been/will be done with more specificity.

\section{Two examples}

Both examples are from larger research programs led by multiple researchers within Art and Crafts, one in Norway and one in Sweden. The Swedish one is led by Lindström, Borg, Lindberg and Johansson. The name of the programme, translated to English, is Communication and learning in Sloyd practices (Sloyd is the Swedish name for an equivalent school subject to Art and Crafts - with a focus on craft). Part study number two is called, the learning qualities in Sloyd. This research programme was presented at the NordFo conferences in Copenhagen 2002, (Lindström et al. 2003) and in Umeå 2006 (Borg \& Johansson 2006).

The Norwegian research program is led by Professor Hjardemaal, with this author as one of many participants. The name of the project is Learning in praxis, the student's competence construction during teacher training studies and in the schools. One part of this study is called: Competence construction in the subject teacher education in Art and Crafts (Hjardemaal \& HiT 2005).

In both projects, the preferred method is "to go out and see what is happening" in a chosen context of application. The researchers engaged in this project are mainly insiders of the field. They all have insider knowledge of the theory and the practice of both the artistic and the pedagogical sector of the field (see figure 1 above). They therefore have an insider view of the problem and of the research process. They have a broad basis for assuming that something is happening and that there is something to look for. And they have the methodological and practical challenge of finding ways to register actually what is happening, not what they think is, or have predicted that should be, happening.

The context of application for the Swedish project is presented through the question (1) "Which knowledge qualities and other values do teachers, principals and pupils think are furthered by good sloyd teaching". What the scope has been further narrowed to, is: (2)"to discuss how teachers and pupils talk and communicate the learning qualities in Sloyd". They hence assume that the teachers and pupils have an opinion or at least an underlying conception of what learning qualities are. They assume further that the teachers and pupils talk and communicate this. Their context of application is therefore communication of learning qualities in the activity.

Thus, when, in 2006, they began their presentation of the results from this study with the question (3) "Are teachers and students working with the same, parallel or different projects?" They indicate that they have found some interesting answers in their study of the communication: the participants communicate about entirely different projects.

These three steps (1-3) in the presentation of the project show a line of thinking: the scope is narrowed down closer and closer to the substance of the learning qualities, and the perceptions of them. This line of thinking is influenced by the different milieu of interests, institutions and practices the researchers represent. It has generated a certain kind of knowledge which it will be brought to the context by identifying and analysing those inconsistencies they have found.

The Norwegian project has not developed to this depth thus far, so I can only estimate roughly the context of application into which it might venture. Preferring the concept "competence" in stead of "knowledge" or "learning" suggests a different theoretical basis than the Swedish project. 
I, as a project participant, have an interesting challenge here to make this project into an insider making profession study when the other participant is a pedagogue. The ambition of making such a project a transdisciplinary Mode 2 project is however a possible one. The title Competence construction in the subject teacher education in Art and Crafts may be especially interesting from such a perspective. My $\mathrm{PhD}$ project gave, from an insider perspective, understanding of some of the dynamics and limiting factors in the activity. Although I only focused on one side of the activity, I gained insight in the situation which led to several new lines of questioning, and thus imput on the problem to be solved (Gulliksen, 2006).

There seems to be a problem in the students' construction of competence in the teacher training of Art and Crafts due to the relationship between the educational competence and the subject specific competence (in art, design and craft). This might be linked to the specific physical environment in the educative situation and the ambiguity of roles available for the students and teachers. Following this line of thought, it is presumed possible to enter into the activity and establish a context of application with questions such as: "How are the different roles communicated?", "How are they utilised in and influencing the students' competence construction?", "Which competence is needed in each context"?

These questions may be the framework for a context of application, but the scope is still too wide. It will be narrowed down through negotiation between the interests of the researchers involved, our conception of the problem and the possible theoretical and methodological approaches we use, and which use we intend the generated knowledge to have. Choosing socio-activity theory (Engeström, Rückriem, \& Lompscher 2005), will give different interpretations than choosing cultural learning theory (Säljö 2000). Choosing availability heuristics (Kahneman 2002) will give different interpretations than system theory (Luhmann 2000). Still, each interpretation may be equally valid and relevant.

\section{Final comments}

In this article I have discussed methodological and theoretical approaches for exploring higher education within Art and Crafts. Making disciplines was defined as a promising path for alternative approaches, and I discussed research on education in Art and Crafts in light of making disciplines and Mode 2 knowledge production. Then I presented some examples of research projects within such a perspective.

Questions that might be raised to these and similar research projects are, how is it possible to conduct research when such different approaches may be considered in the one and same research project? How do we bridge the gap between the different epistemologies or theories, and will this kind of utilitarian attitude towards the different theories make such a study problematic on a disciplinary level? Based in the new mode of knowledge production, the answer to these questions is that such research projects are possible. However, doing problem-based, not discipline based, research in a context of application, amplifies the need for rigorously planning and execution within a stringent framework led by a clear idea of where this new generated knowledge may be useful.

Thus, in my opinion, the most prominent challenge when exploring higher education within Art and Crafts today is to develop research based knowledge on Education in Art and Crafts as a making discipline. As I see it, this will provide a theoretical and methodological basis which may help enabling the practitioners in the field to take full advantage of their insider-knowledge when "researching through" their practices.

An important factor in achieving this is the development of a set of theoretically examined analytical concepts onto which the participants can agree and use as tools in their investigations (Bandini 2002, Gulliksen 2003). Analytical concepts are developed in a theoretical discourse which, as far as possible, separates the concepts from personal consider- 
ations, beliefs or ideological connotations. This is a key condition in developing the history, theory and criticism of the field, thus making it a discipline.

Other challenges are those of cooperation and broader research competence, the utilization of transdisciplinary theoretical perspectives and the different methodological challenges for the insiders when they are studying areas to which they are familiar. One must also consider how participants are economically, loyally, practically or morally bound in different ways to the fields they are studying. These and other challenges are continually addressed by researchers in the above mentioned and other, similar, projects, and I will return more thoroughly to these issues at a later opportunity.

I have deliberately avoided discussing the schism quantitative vs. qualitative studies, and other references to more or less opposing traditions much used in Art and Crafts research. It seems that now the schism between them is somewhat irrelevant. What is relevant is the question: "is this a useful procedure to apply in order to understand this"?

The judgement of the results of this research will then be both whether this newly produced knowledge is reliable, and even more important, as Nowotny states, whether it is socially robust enough to work in today's society (Nowotny 2004, Engeström et al. 2005:1415). This will be the case whether it is research into, on or through Art and Crafts.

\section{Marte Sørebø Gulliksen}

Associate Professor/Førsteamanuensis, PhD

Telemark University College/Høgskolen i Telemark

Email: marte.gulliksen@hit.no

\section{References}

Bandini, Micha. (2002). Theory and/or Method. Paper presented at the Ph.D.Course in History, Theory and Criticism, Oslo School of Architecture.

Borg, Kajsa, \& Johansson, Marlène. (2006). Are teachers and students working with the same, parallel or different projects? Paper presented at the Tradition in Transition - teaching Sloyd, Art and Craftss in Contemporary Society, Umeå, Sweden.

Borgdorf, Henk. (2006). The Debate on Research in the Arts (Vol. 2). Bergen: Kunsthøgskolen i Bergen.

Christiaans, Henri, \& Venselaar, Kees. (2005). Creativity in Design Engineering and the Role of Knowledge: Modelling the Expert. International Journal of Technology and Design Education, 2005(15), 217-236.

Cross, Nigel. Christiaans, Henri, \& Dorst, Kees. (1996). Analysing Design Activity. Chichester: John Wiley \& Sons.

Dunin-Woyseth, Halina, \& Michl, Jan. (2001). Towards a disciplinary identity of the making professions: an introduction. In H. Dunin-Woyseth \& J. Michl (Eds.), The Millennium Reader. Oslo: Oslo School of Architecture.

Dunin-Woyseth, Halina, \& Nielsen, Liv Merete. (2004a). Discussing transdisciplinarity : making professions and the new mode of knowledge production : the nordic reader 2004. Oslo: Oslo School of Architecture and Design.

Dunin-Woyseth, Halina, \& Nielsen, Liv Merete. (2004b). From apprentice to master: some notes on educating design scholars and developing design scholarship. In L. M. Nielsen (Ed.), Design Dialog designforskning i et demokratisk perspektiv. (Vol. 22, pp. S. 15-26). Oslo: Høgskolen i Oslo. http://artsresearch.brighton.ac.uk/links/practice-led/Dunin-Woyseth2003.pdf

Engeström, Yrjö, Rückriem, Georg, \& Lompscher, Joachim. (2005). Putting activity theory to work contributions from developmental work research. Berlin: Lehmanns Media.

Frayling, Christopher. (1993). Research in art and design. Royal College of Art Research Paper Series, 1(1). 
Friedman, Ken. (2003). Theory construction in design research: criteria: approaches, and methods. Design Studies, 2003(24), 507-522.

Gibbons, Michael., et al. (1994). The New Production of Knowledge : the Dynamics of Science and Research in Contemporary Societies. London: Sage.

Gibbons, Michael, \& Scott, Peter. (2001). Re-Thinking Science. Knowledge and the Public in an Age of Uncertainty. Cambridge: Polity Press.

Gulliksen, Marte. (2002). 'Formbilder' i Forming/Kunst og håndverk - en forutsetningsanalyse.Unpublished manuscript, Bergen.

Gulliksen, Marte. (2003). Finnes det en teoretisk drøftingstradisjon innen mitt fagfelt? In J. Sandven (Ed.), Fagkultur og kernefaglighed. Dokumentasjon fra NordFo-symposium Fredriksberg Seminarium 2.-6. oktober 2002 (B:12 ed., Vol. 2003, pp. 160-179). Notodden: NordFo.

Gulliksen, Marte. (2004). Constructing a 'Formbild'. In L. M. Nielsen (Ed.), DesignDialog - designforskning i et demokratisk perspektiv. (Vol. 22/2004, pp. 53-63). Oslo: HiO.

Gulliksen, Marte. (2006). Constructing a Formbild - an inquiery into the dynamical and hierarchical aspects of the hermeneutical filters controlling the formbild construction in design education situations., Oslo School of Architecture and Design, Oslo. http://aho.no/Global/Dokumenter/Forskning/Avhandlinger/Gulliksen_avhandling.pdf

Gulliksen, Marte Sørebø. (2008). Teaching Form Quality in Craft. In L. K. Kaukinen (Ed.), Proceedings of the Crafticulation \& Education Conference (Vol. A: 14/2008). Helsinki: NordFo Techne.

Høgskolen i Oslo. (2009). Kunst og håndverk 30 stp. Retrieved 07.12.2009, from http://www.hio.no/content/download/104234/781309/version/1/file/KH_09.pdf

Høgskolen i Telemark. (2009). Kunst og håndverk, årsstudium. Retrieved 07.12.2009, from http://www.hit.no/nxcnor/content/view/brief/21475

Hjardemaal, Finn, \& HiT. (2005). Læring i praksisfeltet. Studentenes kompetansebygging fra lærerutdanning til yrke. (Prosjektetableringsstøtte). Unpublished Søknad om finansiering, Forskningsrådet. HiT.

Hopperstad, Marit Holm. (2002). Når barn skaper mening med tegning en studie av seksåringers tegninger $i$ et semiotisk perspektiv. Trondheim: Norges teknisk-naturvitenskapelige universitet, Fakultet for samfunnsvitenskap og teknologiledelse, Pedagogisk institutt.

Ingebrethsen, Berit. (2008). Metaforbasert tegning: unders $\phi k t$ som et bildespråksystem gjennom avistegninger avFinn Graff og Saul Steinberg med kognitiv metaforteori som hovedredskap. Arkitektur- og designhøgskolen i Oslo, [Oslo]. http://aho.no/Global/Dokumenter/Forskning/Avhandlinger/Ingebrethsen_web.pdf

Johansson, Marléne. (2002). Slöjdpraktik i skolan : hand, tanke, kommunikation och andra medierande redskap. Göteborg ,: Acta Universitatis Gothoburgensis.

Jonas, Wolfgang. (2006). Research through DESIGN through research - a problem statement and a conceptual sketch. Paper presented at the Wonderground, Lisabon, Portugal.

Kahneman, Daniel. (2002). Maps of bounded rationality: A perspective on intuitive judgement and choice. Retrieved May 15, 2004, from http://www.nobel.se/economics/laureates/2002/kahneman-lecture.html

Kunnskapsdepartementet. (2006). Lareplanverket for Kunnskapslфftet. (2006). Oslo: Utdanningsdirektoratet. from http://www.udir.no/Tema/Lareplaner/

Lindström, Lars, Borg, Kaisa, Johansson, Marlène, \& Lindberg, Viveca. (2003). Kommunikation och lärande i slöjdpraktiker. Forskningsprogram till Vetenskapsrådet, Utbildningsvetenskapliga kommiteen. In J. Sandven (Ed.), Fagkultur og kernefaglighed. Dokumentation fra NordFo-symposium Fredriksberg Seminarium 2.-6.oktober 2002 (Vol. 12/2003). København: NordFo.

Luhmann, Niklas. (2000). Art as a Social System (E. M. Knodt, Trans.). Stanford California: Stanford University Press.

Lutnæs, Eva. (2006). Vurderingskompetanse i faglærerutdanningen. In L. M. Nielsen \& I. Digranes (Eds.), DesignDialog - Kunnskapslфftet og visuell kompetanse (Vol. 24, pp. 59-68). Oslo: HiO-rapport.

Melbye, Ella. (2003). Hovedfagsoppgaver i forming Notodden 1976-1999: faglig innhold sett i lys av det å forme. Porsgrunn: Høgskolen i Telemark. 
Melbye, Ella. (2006). Making profession - fagdidaktiske refleksjoner med feste i hovedfags/masteroppgaver. Paper presented at the Jubileumskonferanse Kunst og Design i skolen 75 år, Oslo, Høgskolen i Oslo.

Melbye, Ella. (2008). To make form in the range between individual and culture. Dissertations in Arts and Crafts Education/(forming) - some deliberations. In J. Sandven (Ed.), Å forme og forske med fokus på skapende prosesser (Vol. 12/2008, pp. 103-137). Notodden: NordFo Techne A.

Nielsen, Liv Merete. (2000). Drawing and spatial representations : reflections on purposes for art education in the compulsory school. [Oslo]: Oslo School of Architecture.

Nielsen, Liv Merete. (2004). Design, innovasjon og demokrati - om framveksten av forskernettverket DesignDialog. In L. M. Nielsen (Ed.), DesignDialog - designforskning i et demokratisk perspektiv. Oslo: HiO.

Nielsen, Liv Merete. (2008). Art, Design and Environmental participation, themes in Norwegian Studies 1995 2007. In L. Lindström (Ed.), Nordic Visual Arts Education in Transition (Vol. 18, pp. 127-145). Stockholm: Vetenskapsrådet. https://pure.dpu.dk/ws/fbspretrieve/365/Nordic_visual_arts_education.pdf\#page=128

Nowotny, Helga. (2004). The potential of transdisciplinarity. In L. M. Nielsen \& H. Dunin-Woyseth (Eds.), Discussing transdisciplinarity : making professions and the new mode of knowledge production : the nordic reader 2004. Oslo: Oslo School of Architecture and Design.

Pedersen, Eirin Marie Solheim. (2004). Om teckning, tecken, text och teori : aktteckning i ett kontextuellt, diskursivt och paradigmatisk perspektiv. [Oslo]: Arkitekthøgskolen i Oslo. http://aho.no/Global/Dokumenter/Forskning/Avhandlinger/pedersen_avhandling.pdf

Refsum, Grete. (2000). Genuine Christian modern art : present Roman Catholic directives on visual art seen from an artist's perspective. [Oslo]: Arkitekthøgskolen i Oslo. http://aho.no/Global/Dokumenter/Forskning/Avhandlinger/Refsum_sammendrag_konklusjon.pdf

Säljö, Roger. (2000). Lärande i praktiken : ett sociokulturellt perspektiv. Stockholm: Prisma.

Utdanning og forskningsdepartementet. (2003). Rammeplan og forskrift for faglaererutdanning $i$ formgiving,kunst og håndverk. Oslo: Norgesnettrådet. http://www.regjeringen.no/upload/kilde/kd/pla/2006/0002/ddd/pdfv/1757902rammeplan_2003 faglaererutd_formkunsthandverk.pdf

Ytterstad, Bente. (2002). "Løse tråder": en artikkelsamling i etterkant av hovedfagsoppgaven "Rettigarnet". Oslo: Høgskolen i Oslo, Avdeling for estetiske fag.

Aakre, Bjørn Magne, \& Randers-Pehrson, Anniken. (2008). Norge: Formgiving, kunst og håndverk. In M. S. Gulliksen \& M. Johansson (Eds.), Nuläge och framåtblickar - om undervisning och forskning inom det nordiska slöjdfältet (Vol. B 15/2008, pp. 45-58). Vasa: NordFo.

\footnotetext{
${ }^{1}$ Based on the trial lecture at my PhD Disputation at Oslo School of Architecture and Design, December 2006.
} 